Isti Rahayu \& Redita Oksadila, Persepesi Mahasiswa terhadap

\title{
Persepsi Mahasiswa Terhadap Kualitas PSAK No.22 (Revisi 2010) Hasil Adopsi IFRS
}

\author{
Isti Rahayu * \\ Redita Oksadila ** \\ Abstract
}

This research aims to reveal the quality perceive of PSAK 22 (revised 2010), it also tests whether there are any differences in quality perceive of PSAK 22 (revised 2010) between students who have read and have not read it. PSAK 22 (revised 2010) resulted in the adoption of IFRS. The research objects are the students of Accounting Department of Economics Faculty of Universitas Islam Indonesia who have undertaken subjects of Advanced Accounting and Business Combination Accounting. The study proves that the students perceive the quality of PSAK 22 (revised 2010) do not meet the qualitative criteria of accounting standards. In addition it also shows that there are differences in quality perceive of PSAK 22 (revised 2010) between students who have read and have not read it.

Keywords: PSAK 22 (revised 2010), perceive, accounting standard, quality, IFRS

\section{Pendahuluan}

Arus globalisasi yang semakin deras telah menghilangkan batasbatas geografis dalam melakukan investasi dan perdagangan, dan mengarah kepada pembentukan satu sistem keuangan dan pasar modal global. Kondisi ini menuntut adanya sistem akuntansi dan pelaporan keuangan yang seragam dan diterima oleh berbagai negara.Untuk mémbangun sistem akuntansi dan pelaporan keuangan yang seragam dibutuhkan standar akuntansi keuangan yang dapat diterima secara internasional maupun global.Harmonisasi atas standar-standar akuntansi dan pelaporan keuangan seluruh dunia mutlak harus dilakukan sebelum membentuk standar akuntansi keuangan global.

Dosen tetap FE UII

Mahasiswa Jurusan Akuntansi FE UII 
Harmonisasi standar akuntansi dan pelaporan keuangan merupakan hal mendesak yang harus dilakukan oleh setiap negara termasuk Indonesia sebagai negara berkembang. Manfaat utama yang diperolah dari harmonisasi standar akuntansi dan pelaporan keuangan adalah adanya pemahaman yang lebih baik atas pelaporan keuangan oleh pengguna laporan keuangan yang berasal dari berbagai negara.Hal ini tentunya memudahkan suatu perusahaan menjual sahamnya secara lintas negara atau lintas pasar modal.

International Accounting Standard Board (IASB) sebagai Dewan Standar Akuntansi Internasional yang berwenang menyusun standar akuntansi internasional untuk penyusunan laporan keuangan perusahaan publik mengeluarkan International Financial Reporting Standard (IFRS).Saat ini IFRS dijadikan sebagai referensi utama pengembangan standar akuntansi keuangan di Indonesia karena IFRS merupakan standar yang sangat kokoh. Penyusunannya didukung oleh para ahli dan dewan konsultatif internasional dari seluruh penjuru dunia.Mereka menyediakan waktu cukup dan didukung dengan masukan literatur dari ratusan orang dari berbagai displin ilmu dan dari berbagai macam jurisdiksi di seluruh dunia.Konvergensi terhadap IFRS memberikan manfaat terhadap keterbandingan laporan keuangan dan peningkatan transparansi. Melalui konvergensi maka laporan keuangan perusahaan Indonesia akan dapat diperbandingkan dengan laporan keuangan perusahaan dari negara lain, sehingga akan sangat jelas kinerja perusahaan mana yang lebih baik. Selain itu, program konvergensi juga bermanfaat untuk mengurangi biaya modal (cost of capital), meningkatkan investasi global, dan mengurangi beban penyusunan laporan keuangan. 
Isti Rahayu \& Redita Oksadila, Persepesi Mahasiswa terhadap

Pengadopsian International Financial Reporting Standards (IFRS)

ke dalam Pernyataan Standar Akuntansi Keuangan (PSAK) oleh Dewan Standar Akuntansi Keuangan sudah dimulai sejak tahun 2008 dan direncanakan akan diadopsi secara utuh pada tahun 2012. Kompleksitas standar akuntansi dan pelaporan keuangan dengan didasarkan pada Standar Akuntansi Keuangan (SAK) yang semula lebih mengacu ke Generally Accepted Accounting Principles (GAAP) kemudian disesuaikan mengacu ke IFRS tentunya akan memberikan masalah tersendiri bagi entitas bisnis di Indonesia, termasuk pada perusahaan yang melakukan kombinasi bisnis atau penggabungan usaha, maupun bagi dunia akademik termasuk mahasiswa .

Penelitian ini bertujuan untuk memperoleh bukti empiris tentang kualitas PSAK No.22 (Revisi 2010) berdasarkan persepsi mahasiswa, dan perbedaan persepsi antara mahasiswa yang sudah pernah dan belum pernah membaca PSAK No.22 (Revisi 2010).

\section{Tinjauan Pustaka}

Di Indonesia kombinasi bisnis atau penggabungan usaha antar perusahaan besar dan terkenal sudah merupakan hal yang sering terjadi apalagi semenjak krisis moneter tahun 1998 yang membuat perusahaan besar mengambil keputusan dan strategi yang sangat berani untuk mempertahankan perusahaan mereka agar tidak mengalami kebangkrutan. Keputusan untuk melakukan penggabungan usaha antar perusahaan masih sering terjadi hingga saat ini.Beberapa perusahaan besar di Indonesia telah melakukan penggabungan usaha karena beberapa alasan seperti 
masalah kesehatan, permodalan, manajemen, teknologi dan supaya memiliki kekuatan untuk menguasai pasar. Pada perusahaan yang melakukan penggabungan usaha akan ada induk perusahaan dan anak perusahaan, dan dengan demikian maka laporan keuangan yang diterbitkan adalah laporan keuangan gabungan antara induk perusahaan dan anak perusahan yang disebut laporan keuangan konsolidasi.

Terkait dengan penggabungan usaha, Pernyataan Standar Akuntansi Keuangan No.22 (Revisi 2010) tentang kombinasi bisnis telah disahkan oleh Dewan Standar Akuntansi Keuangan (DSAK) pada tanggal 12 Januari 2010. PSAK No.22 (Revisi 2010) menggantikan PSAK No.22 (1994) tentang Akuntansi Penggabungan Usaha yang dikeluarkan oleh Komite Prinsip Akuntansi Indonesia pada tanggal 7 September 1994.PSAK No.22 (Revisi 2010) merupakan standar hasil adopsi dari IFRS 3 Business Combination.

Perbedaan secara umum antara PSAK No.22 (Revisi 2010) tentang Kombinasi Bisnis dengan PSAK No.22 (1994) tentang Penggabungan Usaha dapat dilihat pada Tabel 1.

Tabel 1: Perbedaan antara PSAK No.22 (Revisi 2010) tentang Kombinasi Bisnis dengan PSAK No.22 (1994) tentang Penggabungan Usaha

\begin{tabular}{|l|l|l|}
\hline Perihal & PSAK No.22 (Revisi 2010) & \multicolumn{1}{|c|}{ PSAK No.22 (1994) } \\
\hline & Pengecualian untuk: & Pengecualian untuk: \\
& • Under common control & - Under commoncontrol \\
Ruang Lingkup & Pembentukan ventura & - Pembentukan \\
& bersama & venturabersama \\
& $\begin{array}{l}\text { Akuisisi asset atau } \\
\text { kelompok aset yang } \\
\text { bukan merupakan bagian } \\
\text { dari bisnis }\end{array}$ & \\
\hline $\begin{array}{l}\text { Metode } \\
\text { Pencatatan }\end{array}$ & Purchase method & - Purchase Method \\
\hline
\end{tabular}


Isti Rahayu \& Redita Oksadila, Persepesi Mahasiswa terhadap

\begin{tabular}{|c|c|c|}
\hline $\begin{array}{l}\text { Biaya yang } \\
\text { terkait dengan } \\
\text { peroleha akuisisi }\end{array}$ & $\begin{array}{l}\text { Biaya terkait akuisisi } \\
\text { dibebankan pada periode } \\
\text { berjalan }\end{array}$ & $\begin{array}{l}\text { Biaya terkait akuisisi } \\
\text { sebagai bagian biaya akuisisi }\end{array}$ \\
\hline $\begin{array}{l}\text { Pengukuran aset } \\
\text { dánliabilitas } \\
\end{array}$ & $\begin{array}{l}\text { Nilai wajar mengacuke SAK } \\
\text { lain }\end{array}$ & $\begin{array}{l}\text { Terdapat panduan tersendiri } \\
\text { untuk menentukan nilai wajar } \\
\text { dari pos-pos aset dan } \\
\text { liabilitas. }\end{array}$ \\
\hline $\begin{array}{l}\text { Akuisisi } \\
\text { Bẹrtahap }\end{array}$ & $\begin{array}{l}\text { Mengukur kembali } \\
\text { kepemilikan sebelumnya } \\
\text { pada nilai wajar tanggal } \\
\text { akuisisi. } \\
\text { - Selisih antara hasil } \\
\text { pengukuran kembali } \\
\text { tersebut dengan nilai } \\
\text { tercatat sebelumnya } \\
\text { diakui sebagai } \\
\text { keuntungan atau kerugian } \\
\text { dalam laporan laba rugi. } \\
\end{array}$ & $\begin{array}{l}\text { Kepemilikan diukur pada } \\
\text { nilai wajar saat perolehan } \\
\text { (tidak ada pengukuran } \\
\text { kembali). }\end{array}$ \\
\hline $\begin{array}{l}\text { Pengukuran } \\
\text { kepentingan } \\
\text { non pengendali }\end{array}$ & $\begin{array}{l}\text { Berdasarkan nilai wajar, } \\
\text { atau } \\
\text { - Berdasarkan proporsi aset } \\
\text { neto teridentifikasi }\end{array}$ & $\begin{array}{l}\text { Berdasarkan nilai tercatat } \\
\text { aset neto }\end{array}$ \\
\hline Goodwill & $\begin{array}{l}\text { - Goodwill = }=\text { Biaya akuisisi } \\
\text {-Jumlah netoaset } \\
\text { teridentifi kasiyang } \\
\text { diperoleh dan liabilitas } \\
\text { yang diambil-alih } \\
\text { - Goodwill diuji penurunan } \\
\text { nilai setiap akhir periode. }\end{array}$ & $\begin{array}{l}\text { Goodwill = Biaya akuisisi - } \\
\text { Nilai wajar aset dan } \\
\text { liabilitas-Hak } \\
\text { minoritas(berdasarkan nilai } \\
\text { tercatat aset dan liabilitas) } \\
\text { - Goodwill diamortisasi } \\
\text { selama 5 sd } 20 \text { tahun } \\
\end{array}$ \\
\hline $\begin{array}{l}\text { Goodwill } \\
\text { negative }\end{array}$ & $\begin{array}{l}\text { Diakui sebagai keuntungan } \\
\text { periodeberjalan }\end{array}$ & $\begin{array}{l}\text { Diakui sebagaipendapatan } \\
\text { ditangguhkan dan diamortisasi } \\
\text { selama } 20 \text { tahun }\end{array}$ \\
\hline
\end{tabular}

Sümber :Buku PSAK No.22 (Revisi 2010)

Konvergensi PSAK dengan IFRS yang sedang bergulir kencang kemungkinan akan menghasilkan standar akuntansi yang tidak berkualitas dari isi dan bahasa yang sulit dipahami karena proses penerjemahan IFRS menjadi PSAK adalah masalah tersendiri yang menghambat adopsi IFRS di Indonesia. Menurut Purba (2010) proses penerjemahan IFRS (bahasa Inggris) ke dalam bahasa Indonesia terkadang membutuhkan waktu yang relatif lama dan terkadang juga memberikan makna yang berbeda dari 
sumber aslinya. Hal inilah yang memungkinkan terjadinya penafsiran yang ambigu dan perbedaan penafsiran terutama berkaitan dengan istilah akuntansi.

Standar akuntansi yang berkualitas memiliki peranan agar tidak terjadi kesalahan penafsiran dan pemahaman terhadap standar akuntansi tersebut.Standar akuntansi yang kurang berkualitas ditunjukkan dengan bahasa yang sulit dipahami oleh pemakai standar akuntansi (SEC, 2000 dalam Chariri \& Hendro, 2009).Rogero (1998) menyatakan bahwa karakteristik standar akuntansi yang berkualitas ditentukan oleh isi (content) standar tersebut.

Standar akuntansi yang berkualitas sangat penting untuk pengembangan kualitas struktur pelaporan keuangan global.Standar akuntansi yang berkualitas terdiri dari prinsip-prinsip komprehensif yang netral, konsisten, sebanding, relevan dan dapat diandalkan yang berguna bagi investor, kreditur dan pihak lain untuk membuat keputusan alokasi modal (SEC, 2000 dalam Chariri \& Hendro, 2009).

Menurut Levitt (1997) standar akuntansi yang berkualitas harus memenuhi tiga persyaratan, yaitu:

1. Standar berupa kumpulan inti pernyataan akuntansi yang komprehensif.

2. Standar harus dapat diperbandingkan, transparansi dan menyediakan pengungkapan penuh.

3. Standar harus diintepretasikan dan diterapkan dengan tegas.

Sementara Rogero (1998) menyatakan bahwa karakteristik standar. akuntansi yang berkualitas ditentukan oleh isi (content) standar tersebut, yaitu: 
1. Standar ditulis dengan jelas, dapat dimengerti, dan dapat diterapkan secara operasional.

2. Standar menyediakan pedoman pengakuan dan pengukuran yang mendasari transaksi ekonomi.

3. Pengungkapan dapat memberikan kontribusi penting terhadap pengguna laporan keuangan untuk memahami kinerja keuangan. perusahaan

Menurut Anis Chariri \& Kusuma (2009) standar akuntansi yang dihasilkan dengan cara menerjemahkan dari standar akuntansi internasional (IFRS) bukan satu-satunya cara terbaik untuk menghasilkan standar yang berkualitas.Standar akuntansi seharusnya dikembangkan dengan cara yang lebih sistematis sesuai dengan isu-isu yang muncul dalam praktek akuntansi.Dengan kata lain, jika memang standar akuntansi diadopsi dari IFRS, penterjemahaan standar tersebut harus betul-betul dilakukan dengan akurat sesuai dengan konteksnya tidak sekedar diterjemahkan berdasarkan kata-katanya.

Rindu Rika Gamayuni (2009) melakukan penelitian mengenai perkembangan Standar Akuntansi Keuangan Indonesia menuju International Financial Reporting Standards dengan hasil penelitian antara lain Standar Akuntansi Keuangan Indonesia perlu mengadopsi IFRS karena kebutuhan akan info keuangan yang bisa diakui secara global untuk dapat bersaing dan menarik investor secara global. Chariri \& Hendro (2009) melakukan penelitian berkaitan dengan kualitas standar akuntansi hasil adopsi IFRS terhadap PSAK No.55 (Revisi 2006) tentang Pengakuan dan Pengukuran Instrument Keuangan, dan menemukan bahwa standar standar akuntansi keuangan tersebut tidak memenuhi kriteria karena isi (content) dan bahasa yang sulit dipahami. Hal ini juga 
memungkinkan terjadi pada PSAK No.22 (Revisi 2010) yang juga merupakan standar akuntansi hasil adopsi IFRS. Apalagi Kombinasi Bisnis merupakan materi yang cukup kompleks sehingga jika penerjemahan yang dilakukan tidak sesuai maka dapat menimbulkan kesalahan penafsiran dan akan menambah kebingungan bagi pemakai PSAK No.22 (Revisi 2010) yang menjadikannya acuan dalam menyusun laporan konsolidasi, maupun sebagai acuan dalam proses perkuliahan ataupun proses pembelajaran

\section{Hipotesis Penelitian}

Konvergensi PSAK dengan IFRS yang sedang bergulir kencang kemungkinan akan menghasilkan standar akuntansi yang tidak berkualitas dari isi dan bahasa yang sulit dipahami karena proses penerjemahan IFRS menjadi PSAK adalah masalah tersendiri yang menghambat adopsi IFRS di Indonesia. Menurut Purba (2010) proses penerjemahan IFRS (bahasa Inggris) ke dalam bahasa Indonesia terkadang membutuhkan waktu yang relatif lama dan terkadang juga memberikan makna yang berbeda dari sumber aslinya. Hal inilah yang memungkinkan terjadinya penafsiran yang ambigu dan perbedaan penafsiran terutama berkaitan dengan istilah akuntansi.Chariri \& Hendro (2009) menemukan bahwa PSAK No.55 (Revisi 2006) tentang Pengakuan dan Pengukuran Instrument Keuangan yang merupakan hasil adopsi IFRS, tidak memenuhi criteria kualitas karena isi (content) dan bahasa sulit dipahami. Berdasarakan uraian diatas maka dapat dirumuskan hipotesis : 
Isți Rahayu \& Redita Oksadila, Persepesi Mahasiswa terhadap

H1 : PSAK No.22 (Revisi 2010) tentang Kombinasi Bisnis tidak memenuhi criteria sebagai standar akuntansi yang berkualitas.

Persepsi mahasiswa mengenai kualitas PSAK No.22 (Revisi 2010) antara lain dipengaruhi oleh kefamiliaran mahasiswa terhadap PŚAK tersebut. Sebagian mahasiswa diduga ada yang belum pernah membaca PSAK No.22 (Revisi 2010) namun ada juga mahasiswa yang diduga sudah pernah membaca.Dari latar belakang pengetahuan mengenai PSSAK No.22 (Revisi 2010) yang berbeda tersebut kemungkinan dapat menimbulkan persepsi yang berbeda mengenai kualitas dari PSAK No.22 (Revisi 2010). Berdasarkan uraian di atas maka dapat dirumuskan hipotesis:

H2 : Terdapat perbedaan persepsi kualitas PSAK No.22 (Revisi 2010) antara mahasiswa yang sudah membaca dengan mahasiswa yang belum membaca PSAK No.22 (Revisi 2010)

\section{Metode Penelitian}

\section{Populasi dan Sampel}

Populasi dalam penelitian ini adalah Mahasiswa Aktif Program Studi Akuntansi S1 Universitas Islam Indonesia. Pengambilan sampel dilakukan secara purposive dengan membagikan kuesioner kepada mahasiswa yang telah mengambil mata kuliah Akuntansi Keuangan Lanjutan dan sedang mengambil mata kuliah Akuntansi Kombinasi Bisnis. Dari 202 kuesioner yang dibagikan, 195 kembali dan sebanyak 172 kuesioner atau $85,2 \%$ memenuhi syarat untuk diolah. 


\section{Variabel Penelitian}

Standar akuntansi yang berkualitas adalah standar akuntansi yang memenuhi persyaratan sebagaimana dinyatakan Rogero (1998), yaitu:

1. Standar seharusnya ditulis dengan jelas, dapat dimengerti, dan prinsip dapat diterapkan secara operasional.

2. Standar menyediakan pedoman pengakuan dan pengukuran serta pengungkapan yang mendasari transaksi ekonomi.

3. Pengungkapan dapat memberikan kontribusi penting terhadap pengguna laporan keuangan untuk memahami kinerja keuangan perusahaan.

Dalam penelitian ini kualitas standar akuntansi diukur dengan Kuesioner yang disusun dalam kalimat-kalimat pernyataan. Jawaban dari responden di ukur dengan menggunakan Skala Likert (1 sampai 5) yang meliputi Definisi Kombinasi Bisnis, Metode Akuisisi, Pengukuran, Pengakuan dan Pengungkapan sebagaimana yang dipergunakan oleh Anis Chariri dan Sonny Kusuma (2009) dengan menyesuaikan konteks penelitian Akuntansi Kombinasi Bisnis. Pengukuran dengan skala likert 5 angka dimulai dari $1=$ Sangat Sulit Dipahami ; $2=$ Sulit Dipahami ; $3=$ Netral ; $4=$ Mudah Dipahami dan $5=$ Sangat Mudah Dipahami.

Kombinasi Bisnis sebagai suatu transaksi atau peristiwa lain yang pihak pengakuisisi memperoleh pengendalian atas satu atau lebih bisnis diukur dengan 1 pertanyaan. Metode akuisisi yang diterapkan pada kombinasi bisnis diukur menggunakan 3 pertanyaan.Pengakuan asset teridentifikasi yang diperoleh, liabilitas yang diambil alih dan kepentingan non pengendali pada pihak yang diakuisisi diukur menggunakan 6 pertanyaan.Pengukuran asset teridentifikasi yang 
diperoleh, liabilitas yang diambil-alih dan kepentingan non pengendali pada pihak yang diakuisisi dengan nilai wajar pada tanggal akuisisi diukur menggunakan 6 pertanyaan.Pengungkapan informasi yang dibutuhkan pengguna laporan keuangan diukur menggunakan 2 pertanyaan.Semua pertanyaan dalam kuesioner ini diambil dari PSAK No.22 (Revisi 2010).

Sedangkan pendapat mahasiswa mengenai kualitas PSAK No.22 (Revisi 2010) diukur menggunakan 3 pertanyaan. Pengukuran dengan skala likert 5 angka dimulai dari $1=$ Sangat Tidak Setuju ; $2=$ Tidak Setuju ; $3=$ Netral $; 4=$ Setuju dan $5=$ Sangat Setuju.

\section{Metode Pengujian Hipotesis}

Hipotesis pertama $(\mathrm{H} 1)$ di uji dengansign testdengan membandingkan nilai rata-rata (mean) jawaban responden dengan nilai tengah (median). Sedangkan Hipotesis kedua (H2) di uji dengan $T$ Test yaitu dengan independen samples test. Pengujian hipotesis dilakukan dengan menggunakan Alpha $=0,05$.

\section{Hasil Penelitian}

\section{Hasil Uji Validitas}

Uji validitas digunakan untuk mengetahui valid tidaknya instrument pengukuran. Instrumen dikatakan valid apabila dapat mengukurapa yang semestinya diukur atau mampu mengukur apa yang ingin dicarisecara tepat .Hasil pengujian validitas terlihat pada table 1 berikut ini: 
Tabel 2: Hasil Uji Validitas

\begin{tabular}{|l|c|c|c|}
\hline & Pertanyaan & Pearson & Kesimpulan \\
\hline $\begin{array}{l}\text { Definisi Kombinasi } \\
\text { Bisnis }\end{array}$ & KSA1 & 0,661 & Valid. \\
\hline Metode Akuisisi & KSA2 s.d. KSA4 & $0,694-0,762$ & Valid \\
\hline Pengakuan & KSA5 s.d. KSA10 & $0,572-0,804$ & Valid \\
\hline Pengukuran & KSA11 s.d. KSA16 & $0,651-0,815$ & Valid \\
\hline Pengungkapan & KSA17 s.d. KSA18 & $0,784-0,821$ & Valid \\
\hline Kesimpulan & KSA19 s.d. KSA21 & $0,388-0,457$ & Valid \\
\hline
\end{tabular}

Sumber : Data yang diolah,2012

Berdasarkan hasil uji validitas di atas terlihat bahwa masing-masing item pertanyaan dalam kuesioner dari setiap variabel mempunyai koefisien di atas 0,30.Dengan demikian masing-masing item pertanyaan dalam kuesioner dapat dinyatakan valid.

\section{Hasil Uji Realibilitas}

Uji realibilitas ini dilakukan dengan menggunakan perkiraan Alpha Cronbach yang menunjukkan bagaimana tingginya butir-butir dalam kuisioner berinteraksi. Uji realibilitas ini dilakukan untuk mengetahui adanya penyimpangan atau deviasi yang mungkin disebabkan adanya berbagai faktor acak dalam proses pengukuran. 
Tabel 3:Hasil Uji Reliabilitas

\begin{tabular}{|c|c|c|c|}
\hline & Pertanyaan & $\begin{array}{c}\text { Cronbach's } \\
\text { Alpha }\end{array}$ & Kesimpulan \\
\hline $\begin{array}{l}\text { Definisi Kombinasi } \\
\text { Bisnis }\end{array}$ & KSA1 & - & - \\
\hline Metode Akuisisi & $\begin{aligned} & \text { KSA2 } \text { s.d. } \\
& \text { KSA4 }\end{aligned}$ & 0,835 & Reliabilitas Baik \\
\hline Pengakuan & KSA5 s.d.KSA10 & 0,856 & Reliabilitas Baik \\
\hline Pengukuran & KSA11 s.d. KSA16 & 0,891 & Reliabilitas Baik \\
\hline Pengungkapan & KSA17 s.d. KSA18 & 0,863 & Reliabilitas Baik \\
\hline Kesimpulan & KSA19 s.d. KSA21 & 0,683 & $\begin{array}{c}\text { Reliabilitas } \\
\text { diterima }\end{array}$ \\
\hline
\end{tabular}

Sumber : Data yang diolah,2012

Berdasarkan hasil uji Reliabilitas pada Tabel 4.9.terlihat bahwa nilai Cronbach's Alpha masing-masing item pertanyaan dari setiap variabel dalam kuesioner semua bernilai $>0,60$. Dengan demikian masing-masing item pertanyaan dalam kuesioner dapat dinyatakan reliabel terkecuali untuk definisi.

\section{Hasil Pengujian Hipotesis}

Hipotesis 1 menyebutkan bahwa PSAK No.22 (Revisi 2010) tentang Kombinasi Bisnis tidak memenuhi criteria sebagai standar akuntansi yang berkualitas.

Tabel 4: Statistik Deskriptif

\begin{tabular}{|c|c|c|c|}
\hline & $\mathbf{N}$ & Mean & Std. Deviation \\
\hline Median & 172 & 3.0000 & .00000 \\
\hline $\begin{array}{l}\text { Mean Persepsi Mahasiswa } \\
\text { PSAK No.22 (Revisi 2010) }\end{array}$ & 172 & 2.8422 & .57341 \\
\hline
\end{tabular}

Sumber : Data yang diolah,2012 
' 1:" Tabel diatas menunjukan bahwa Mean teoritis rata-rata Persepsi Mahasiswa terhadap PSAK No.22 (Revisi 2010) sebesar 2,8422 .Hal ini menunjukkan bahwa mahasiswa kesulitan dalam memahami isi PSAK No.22 (Revisi 2010). Selanjutnya hasil pengujian sign test terdapat 102 responden memiliki nilaipersepsi rata-rata kurang dari 3 (negative difference), 60 responden memiliki nilai persepsi rata-rata lebih dari 3 (positive difference) dan 10 responden memiliki nilai rata-rata sama dengan 3 (ties). Jadi $\mathrm{N}$ untuk hipotesis 1 adalah 162 responden.Hasil pengujian hipotesis 1 dapat dilihat pada Tabel 4.

Tabel 5: Hasil Sign Test Hipotesis 1

Z

Sumber : Data yang diolah,2012

Dari hasil pengujian tingkat signifikannya diperoleh bahwa nilai probabilitas signifikannya adalah 0,001 lebih kecil dari Alpha $=0,05$ sehingga dari pengujian tersebut dapat disimpulkan bahwa hipotesis pada penelitian ini didikung data. Hal ini menunjukkan bahwa PSAK No.22 (Revisi 2010) tentang kombinasi bisnis tidak memenuhi kriteria sebagai standar akuntansi yang berkualitas menurut persepsi mahasiswa.

Hipotesis 2 menyebutkan bahwa terdapat perbedaan persepsi kualitas PSAK No.22 (Revisi 2010) antara mahasiswa yang sudah membaca dengan mahasiswa yang belum membaca PSAK No.22 (Revisi 2010). Pengujian T-test menunjukkan bahwa nilai .rata-rata persepsi mahasiswa yang sudah pernah membaca PSAK No.22 (Revisi 2010) tentang kombinasi bisnis lebih tinggi dari pada mean mahasiswa yang belum pernah membaca. 
Isți Rahayu \& Redita Oksadila, Persepesi Mahasiswa terhadap

Tabel 6: Hasil Pengujian Perbedaan Rata-Rata Sampel

\begin{tabular}{|l|c|c|c|c|c|}
\hline & $\begin{array}{c}\text { Baca PSAK } \\
\text { No.22 (Revisi } \\
\text { 2010) }\end{array}$ & $\mathrm{N}$ & Mean & $\begin{array}{r}\text { Std. } \\
\text { Deviation }\end{array}$ & $\begin{array}{c}\text { Std. } \\
\text { Error } \\
\text { Mean }\end{array}$ \\
\hline $\begin{array}{l}\text { Mean Persepsi } \\
\text { Mahasiswa PSAK } \\
\text { No.22 (Revisi 2010) } \\
1\end{array}$ & Sudah & 14 & 3.4422 & .47890 & .12799 \\
\cline { 2 - 6 } & Belum & 158 & 2.7890 & .55153 & .04388 \\
\hline $\begin{array}{l}\text { Fig. 0.196 } \\
\text { Sig. }\end{array}$ & & & & & \\
\hline
\end{tabular}

Sumber : Data yang diolah,2012

Hasil pengujian juga menunjukkan bahwa $F$ hitung levene test 0,196 dengan nilai probabilitas 0,000 atau lebih kecil dari 0,05 yang berarti signifikan pada taraf signifikansi $5 \%$ sehingga dari pengujian tersebut dapat disimpulkan bahwa hipotesisditerima.Persepsi mahasiswa mengenai kualitas PSAK No.22 (Revisi 2010) tentang kombinasi bisnis. antara mahasiswa yang sudah pernah membaca dengan persepsi mahasiswa yang belum pernah membaca berbeda signifikan.

Kesimpulan dan Saran

Kesimpulan

Penelitian ini membuktikan bahwa PSAK No.22 (Revisi 2010) tidak memenuhi kriteria sebagai standar akuntansi yang berkualitas menurut persepsi mahasiswa.Penelitian ini juga berhasil membuktikan terdapat perbedaan persepsi mahasiswa mengenai kualitas PSAK No.22 (Revisi 2010) antara mahasiswa yang sudah pernah membaca dan mahasiswa yang belum pernah membaca PSAK No.22 (Revisi 2010). 


\section{Keterbatasan dan Saran Penelitian Selanjutnya}

Penelitian ini memiliki sejumlah keterbatasan yang mungkin mempengaruhi hasil penelitian yang dicapai, antara lain:

i) Penelitian ini hanya terbatas pada mahasiswa akuntansi SI dari Fakultas Ekonomi Universitas Islam Indonesia yang sedang mengambil mata kuliah Akuntansi Kombinasi Bisnia pada semester 1 2011, sehingga pemahaman para mahasiswa belum komprehensif karena proses perkuliahan sedang berlangsung. Oleh karena itu penelitian selanjutnya pengambilan sampel agar dilakukan untuk mahasiswa yang telah mengambil mata kuliah Akuntansi Bisnis.

2) Penelitian tidak melihat kualitas PSAK No.22 (Revisi 2010) berdasarkan tingkat pemahaman mahasiswa yang dapat dilihat dari nilai. matakuliah akuntansi kombinasi bisnis yang menggunakan PSAK No.22 (Revisi 2010) sebagai acuannya. Diharapkan pada penelitian selanjutnya dapat dilakukan penelitian berkaitan dengan tingkat pemahaman tersebut.

3) Penelitian ini hanya terbatas dari persepsi mahasiswa yang lebih banyak dipengaruhi oleh, kesadaran, ingatan, pikiran dan bahasa sehingga persepsi bukanlah cerminan yang tepat dari realitas, dan akan bersifat sangat subjektif. Oleh karena itu pada penelitian selanjutnya diharapkan dapat menggunakan nilai matakuliah akuntansi kombinasi bisnis atau Akuntansi Keuangan Lanjutan sebagai salah satu faktor yang mempengaruhi persepsi mahasiswa sehingga akan lebih bersifat objektif. Kuesioner dalam penelitian ini hanya memfokuskan pada isi PSAK No.22 
Istị Rahayu \& Redita Oksadila, Persepesi Mahasiswa terhadap

(Revisi 2010) tanpa ada batasan tentang karakteristik standar akuntansi yang berkualitas sehingga pada kuesioner penêtitian selanjutnya diharapkan untuk memasukan karakteristik standar ", akuntansi yang berkualitas sebagai variabelnya. 


\section{Daftar Pustaka}

Anis Chariri \& Sonny Kusuma S.H., Menguji Kualitas Standar Akuntansi Hasil Adopsi IFRS: Studi Empiris Pada PSAK No.55 (Revisi 2006), Simposium Nasional Akuntansi XIII Purwokerto, 2010.

Baker, RE (2005), Advanced Financial Accounting, McGraw-Hill Companies,Inc

Dwi Martani, PSAK-22: Kombinasi Bisnis, 2011. http://staff.blog.ui.ac.id/martani/files/2001/PSAK-22-KombinasiBisnis.pdf

Ersa Tri Wahyuni, Konfergensi IFRS dan Implikasinya Terhadap Dunia Pendidikan Akuntansi di Indonesia, Economic and Business Review (EBAR), February 2010. http://ersatriwahyuni.blogspot.com/2010/07/konvergensi-ifrs-dan implikasinya.html

IKatan Akuntan Indonesia, PSAK 22 (Revisi 2010(: Kombinasi Bisnis, IAI, 2010

Levitt, A., The Importance of High Quality Accounting Standards, Accounting Horizons, Vol.12, No.1,pp.79-82, 1998

Purba, M. P., International Financial Reporting Standards : Konvergensi \& Kendala Aplikasinya di Indonesia, Graha Ilmu, Yogyakarta, 2010.

Rindu R. Gamayuni, Perkembangan Standar Akuntansi Keuangan Indonesia Menuju International Financial Reporting Standards, Jurnal Akuntansi dan keuangan, Vol.14 No.2, Fakultas Ekonomi Universitas Lampung, Juli 2009,Hal.153-166. http://lemlit.unila.ac.id/file/arsip\%202010./JAK/JAk\% 20Juli\%202009.pdf

Rogero, L.H., Characteristics of High Quality Accounting Standards, Accounting Horizons, Vol. 12, No.2, pp. 177-183, 1998.

Suwardjono, Teori Akuntansi: Perekayasaan Pelaporan Keuangan. BPFE Yogyakarta, Yogyakarta, 2010. 